\section{Over here and over there}

\author{
Stephen Hancocks OBE \\ Editor-in-Chief
}

Send your comments to the

Editor-in-Chief,

British Dental Journal

64 Wimpole Street,

London

W1G 8YS

Emailbdj@bda.org
Having an adversary sometimes has positive outcomes. A small scale example might be the bonding exchanges between passengers that result on public transport, otherwise devoid of human conversation, when the train stops because of a signal failure, or on a bus becalmed by traffic. The oft quoted wartime spirit of uniting against a common enemy is an occurrence on a larger scale, as anecdotes tell of tearing down park railings to make Spitfires or crowding into tube stations for air raid protection with alleged irrepressible good humour.

This latter elevation of national moral fibre has been suddenly revived in recent weeks as we in the UK have been dragged unexpectedly into the debate raging in the USA as a result of President Obama's proposed healthcare reforms. Blustering right-wing senators and what appear to be somewhat rabid anticommunist American citizens have been lambasting 'socialised medicine' as if were the new plaque itself. In the process many have directed their ire across the Atlantic, citing the National Health Service as the very devil incarnate apparently depleting people of their healthcare choice and sucking the life blood from the nation's finances. This conveyor belt of politicians and others on our television screens decrying the NHS has stirred us to righteous indignation in defence of what has in reaction become a 'national treasure' and a source of great pride.

In view of the criticisms of the NHS, especially NHS dentistry, from within the UK in recent times this might strike one as being somewhat hypocritical. Perhaps it is a case of it being acceptable for us to criticise it but not so those from outside. This sense of outrage is no doubt heightened when on this side of the ocean we perceive the American system to be unjust and unequal in terms of healthcare access to all who need it, especially to treatment for acute conditions. An instance of how dare they pass judgment on us while their own house is in disorder?

\section{PERSONAL AFFORDABILITY AND STATE CO-ORDINATION}

It does seem that as one of the wealthiest countries in the world, America has a moral issue to tackle in having such a large proportion of its citizens not covered by healthcare due to the cost of insurance. The degree of compassion in a society is often measured by the way in which the young, old and sick are cared for, or not, and it is sometimes difficult to believe that, as the lyrics to the Star Spangled Banner have it 'the land of the free and the home of the brave' would base its access to healthcare on a system of personal affordability rather than state co-ordination. But then, if I am not to be hypocritical either, I don't live there, I can afford to pay the insurance when I travel there and is it any of my business anyway?

However, not all utterances here have been in defence of 'our' Service. Opinions have been aired in agreement with the international detractors that the NHS is not appropriate to the twenty-first century and that the cost-benefit balance needs to be reassessed and readjusted. Are these Quisling voices or are they merely reflecting a reality? Discussion on this is in any case going to be a necessity forced upon us soon as the looming cost of 'qualitative easing' and the other measures that have required such massive government borrowing lead to cuts in public spending.

Perhaps this external attack, albeit by individuals rather than an angry state, does provide us with an opportunity to stand back for a moment and assess our own attitude towards the NHS. How is it that we moan about it so constantly and yet rush to its defence the moment anyone dares to question its value? Does the dichotomy reflect an emotional attachment that clouds our judgement of its perceived value as distinct from its hard actual worth? Is the knee-jerk defence one of protection born of familiarity rather than rational assessment?

Interestingly, dentistry has hardly formed a speck in the dustclouds of the affray. While one might argue that it is small beer indeed beside the multi-billion dollar mammoth of the medical healthcare industry, it is nevertheless worth considerable bucks and no doubt the 160,000 plus US dentists and the American Dental Association are monitoring the situation very carefully. Being honest, while we might leap to the defence of the NHS in general and in terms of medical care, how many of us would find ourselves on the side the red-neck Republicans in disparaging NHS dentistry? Would we wholeheartedly stand our ground and advocate that America adopts the UDA system or would we suggest that some form of hybrid arrangement might be a better deal all round, for patients and for clinicians?

As an unexpected intrusion into our own front room, the US debate has stirred national pride. As such will the rude interruption provide us with an opportunity to try and separate the emotional attachment from the reality of modern disease distribution, available resources and realistic financial balance? Over there and over here; maybe the social geography is closer than we think.

DOI: $10.1038 /$ sj.bdj.2009.825 